\title{
A Case Study of Heavy Metal Pollution in Water of Bone River by Artisanal Small-Scale Gold Mine Activities in Eastern Part of Gorontalo, Indonesia
}

\author{
Nurfitri Abdul Gafur ${ }^{1, *}$, Masayuki Sakakibara ${ }^{1,2,3}{ }^{\mathbb{D}}$, Sakae Sano ${ }^{4}$ and Koichiro Sera ${ }^{5}$ \\ 1 Department of Earth Science, Graduate School of Science and Engineering, Ehime University, \\ Ehime 790-8577, Japan; sakaki@chikyu.ac.jp \\ 2 Faculty of Collaborative Regional Innovation, Ehime University, Ehime 790-8577, Japan \\ 3 Research Institute for Humanity and Nature, Kyoto 603-8047, Japan \\ 4 Faculty of Education, Ehime University, Ehime 790-8577, Japan; sano.sakae.mm@ehime-u.ac.jp \\ 5 Cyclotron Research Centre, Iwate Medical University, Iwate 020-8505, Japan; ksera@iwate-med.ac.jp \\ * Correspondence: vivinurv3@hotmail.com
}

Received: 30 August 2018; Accepted: 17 October 2018; Published: 24 October 2018

\begin{abstract}
Bone River, which is located in the eastern part of Gorontalo, Indonesia, has an issue of contamination by heavy metals due to artisanal small-scale gold mine (ASGM) activities. This river is used as a source of water by inhabitants living along the river, due to the lack of another clean water supply. The purpose of this study is to investigate the concentration of As from the mining site alongside Bone River, and to reveal the As pollution source. Water and sediment samples were collected from ASGM and along Bone River to the delta. The concentrations of $\mathrm{As}, \mathrm{Hg}$, and $\mathrm{Pb}$ in water samples were identified by inductively coupled plasma mass spectroscopy (ICP-MS), while concentrations in sediment samples were determined by particle-induced $X$-ray emission (PIXE). Results showed that the concentrations of $\mathrm{As}, \mathrm{Hg}$, and $\mathrm{Pb}$ in water ranged from 66 to $82,500 \mu \mathrm{g} / \mathrm{L}$, 17 to $2080 \mu \mathrm{g} / \mathrm{L}$, and 11 to $1670 \mu \mathrm{g} / \mathrm{L}$, respectively. These levels exceeded, by 1000 to 10,000 times, the safe limits of drinking water defined by the World Health Organization, which indicated that Bone River water is not safe for drinking or cooking purposes.
\end{abstract}

Keywords: heavy metal; metalloid; ASGM; river water

\section{Introduction}

Heavy metals are produced from natural and anthropogenic sources and can build-up in sediments, having significant environmental implications for local communities, as well as for river water quality [1]. Heavy metals are known to be toxic and containing carcinogenic metalloids that can cause cancer in the skin, lungs and urinary tracts; cardiovascular disease; neurotoxicity; and diabetes [2-7]. Gold mining is a source of heavy metals, one of the most serious environmental problems in the world. Specifically, artisanal small-scale gold mines (ASGM) are an important source of heavy metals because the extracted material may contain harmful metals, such as $\mathrm{As}$ and $\mathrm{Pb}$. ASGM commonly use $\mathrm{Hg}$ for gold extraction because it is quite cheap, can be handled easily, and can form an amalgam with gold. Due to the lack of attention to health awareness, the miners usually ignore the health risk associated with $\mathrm{Hg}$ during amalgamation [8]. Miners in ASGM have also used cyanide instead of mercury for gold extraction since 1889 [8-11], as was the case in Huanca village, Peru, where mercury and arsenic concentrations were found in surface soil samples of the area of Huanca settlement and the agricultural land adjacent to the Acarí River. It was suggested that those concentrations were linked to the gold ore as they reached maximum concentrations $\left(48.4 \mathrm{mg} \cdot \mathrm{kg}^{-1}\right)$ 
at the site of an old grinding process in the mining site [8]. People in Bone Bolango Regency are concerned that the water was contaminated by heavy metals and metalloids due to ASGM.

Within the aquatic environment, the sediments have been broadly utilized as natural pointers for the assessment of metal contamination in the water [12]. Sediments settle, diminishing their bioavailability. However, dangerous substances like heavy metals and metalloids are shown in a number of a chemical forms trapped in the sediments. As these can build up to create a reservoir, they constitute a possible peril for the downstream valley [12-14].

The objectives of this study were (i) to investigate the concentration of heavy metals such as $\mathrm{As}, \mathrm{Hg}$, and $\mathrm{Pb}$ in water from mining sites along the Bone River; and (ii) to reveal the heavy metal pollution source in water from the upper course of Bone River, close to ASGM, to the lower course of the river, near the delta.

\section{Materials and Methods}

\subsection{Research Locality}

The present study was conducted along Bone River, which is located in the eastern part of Gorontalo, Indonesia. Artisanal small-scale gold mining activities are located in the upper course of Bone River. Bone River characteristics are $1 / 1800$ to $1 / 1250$ of riverbed slope, $120 \mathrm{~m}$ to $220 \mathrm{~m}$ of river width, $\pm 2.3 \mathrm{~m}$ of water depth, and about 210 to $870 \mathrm{~m}^{3} / \mathrm{s}$ of carrying capacity [15].

\subsection{Sampling}

Water and sediment samples were collected from mine tailings, along with the main stream of Bone River, and the delta of the river (Figure 1). After determining the location of the sampling points, 11 water samples, consisting of two samples from gold mining wastewater and nine water samples from the upper course to the delta of Bone River, were collected in different bottles from the laboratory. Samples of water were acidified with $3 \%$ nitric acid, along with other samples, and were transferred to the laboratory for As and other metals analysis.

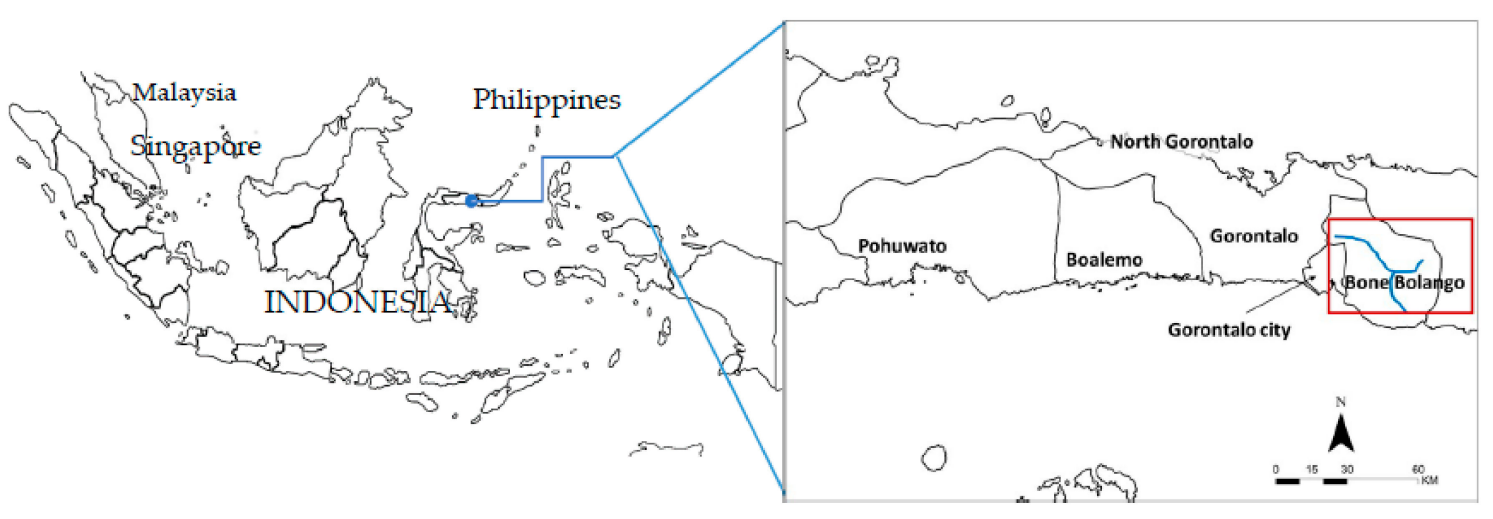

Figure 1. Field site characteristics.

A total of $50 \mathrm{~g}$ of sediment samples, from a depth of $20 \mathrm{~cm}$ under the riverbed, were collected [5]. The collected samples were coarse sand to clay material (as much as 2 to $0.002 \mathrm{~mm}$ ) with the wet density from 1 to $2 \mathrm{~g} / \mathrm{cm}^{3}$. All the samples were preserved in autoclaved sample bags. The sediment samples were imported under the permit of the minister of Agriculture, Forestry, and Fisheries, Japan in accordance with the Plant Protection Law. The sediment samples were dried in a laboratory for about $48 \mathrm{~h}$ at $120^{\circ} \mathrm{C}$. Following this, samples were homogenized by grinding in an agate mortar and stored in labeled bottles until chemical analysis. 


\subsection{Analytical Method}

Each of the collected water samples was first filtrated from the suspension by $0.45 \mu \mathrm{m}$ membrane filter (Whatman Merck Millipore Corporation, Darmstadt, Germany). The filtrated water samples were diluted with $3 \% \mathrm{HNO}_{3}$ to a final volume of $10 \mathrm{~mL}$ for analysis. The concentrations of heavy metal in water samples were determined using a Varian 820-MS instrument (Agilent Technologies, Santa Clara, CA, USA) analysis with inductively coupled plasma mass spectroscopy (ICP-MS) using a Varian 820-MS instrument (Agilent Technologies, Santa Clara, CA, USA) at the Integrated Center for Sciences, Ehime University. All treatments were replicated three times. Reagent blanks and internal standards were used where appropriate to ensure accuracy and precision. A certified reference material (NIST1634f) [16] provided by the National Institute of Standards and Technology (NIST) of Japan was used for analytical accuracy and precision. The analysis of the reference material was accurate, indicating a high level of reproducibility. The analytical calibration curve was created using a multi-element calibration standard (PerkinElmer, Inc., Massachusetts, MA, USA). Rhodium standard solution (Wako Pure Chemical Industries, Ltd., Osaka, Japan) was used as the internal standard. The sediment samples were taken at about $20 \mathrm{~cm}$. They were dried in a ventilated oven at $120^{\circ} \mathrm{C}$ for $48 \mathrm{~h}$. The dried samples were ground to a fine size, and homogenized for analysis of particle-induced X-ray emission (PIXE) at Cyclotron Research Center, Iwate Medical University, Japan. For PIXE analysis, the homogenized sediment samples were mixed with $\mathrm{Pd}-\mathrm{C}$ as an internal standard with the ratio of 3:1, then set up onto a thin film holder by using collodion solution and bombarded with a $2.9 \mathrm{MeV}$ proton beam energy from a cyclotron [17].

\subsection{Quality Control}

National Institute of Standard and Technology (NIST) CRM 1643f standard reference material [16] and Multi-element standard XSTC-13 from SPEX CertiPrep (NZ, USA) [18] were used to validate the results of $\mathrm{As}, \mathrm{Hg}$ and $\mathrm{Pb}$ in water. The $\mathrm{As}, \mathrm{Hg}$ and $\mathrm{Pb}$ concentrations in sediment were determined in the certified reference material National Institute of Standard and Technology (NIST) SRM 2782 [19].

\section{Results}

Figure 2. below shows the location of water and sediment samples which derived from ASGM site. In this study, the process of getting gold from ASGM in Bone Bolango Regency includes using two types of gold process (i.e., elemental $\mathrm{Hg}$ and cyanide). After digging, crushing and grinding the rock to fine materials, miners mix the $\mathrm{Hg}$ for amalgamation. The $\mathrm{pH}$ of an aquatic system, and the quantity of trace metals or metalloids present, indicate its water quality. The acceptable normal range of $\mathrm{pH}$, per guidelines suggested by $\mathrm{WHO}$, is about 6.5 to 8.5 [20,21]. The obtained results of $\mathrm{pH}$ values of mining (W1) and tailing waters (W2) were 1.98 and 4.00, respectively. This result indicates that the acidic water may release other metal ions such as $\mathrm{Pb}$. On the other hand, the $\mathrm{pH}$ value of river water ranges from 7.53 to 7.82 (W3-W11), which indicates the slightly alkaline nature of the river water. The $\mathrm{pH}$ in this research is close to the limits recommended by WHO for drinking water. 


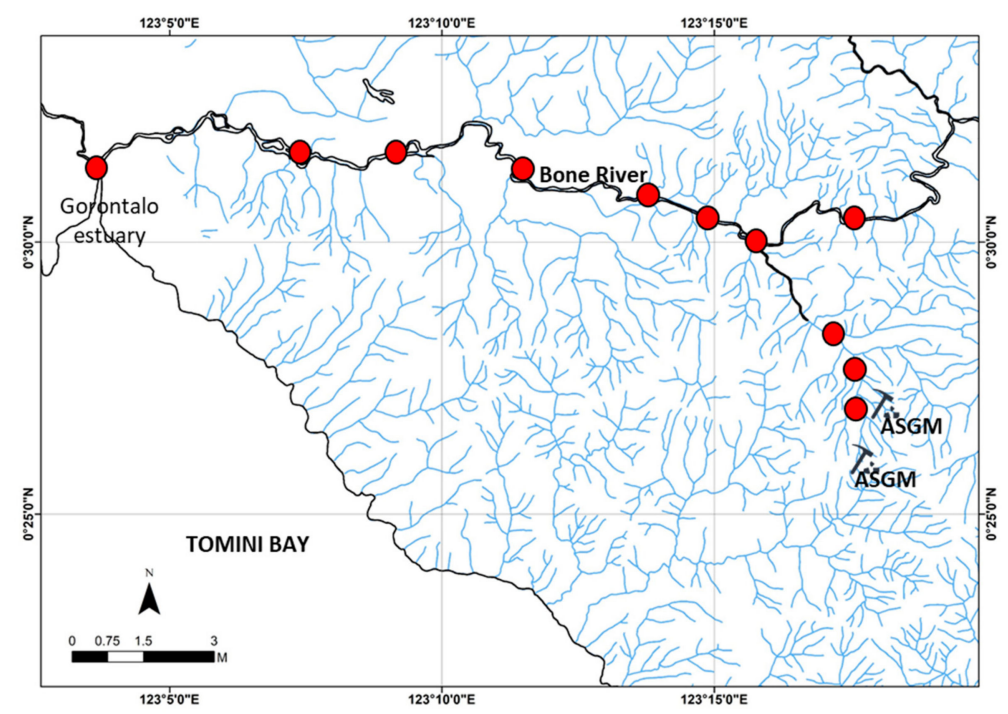

Figure 2. Water and sediment sampling points from the upper course to the lower course of Bone River.

The $\mathrm{As}, \mathrm{Hg}$, and $\mathrm{Pb}$ concentrations in water and sediment samples from the studied sites are presented in Tables 1 and 2. Concentrations of $\mathrm{As}, \mathrm{Hg}$, and $\mathrm{Pb}$ in water samples ranged from 66 to $82,500 \mu \mathrm{g} / \mathrm{L}, 17$ to $2080 \mu \mathrm{g} / \mathrm{L}$, and 11 to $1670 \mu \mathrm{g} / \mathrm{L}$, respectively. The results of this study revealed that the water contained $\mathrm{As}, \mathrm{Hg}$, and $\mathrm{Pb}$ concentrations exceeding the threshold value established by WHO guidelines for water (i.e., $10 \mu \mathrm{g} / \mathrm{L}, 6.0 \mu \mathrm{g} / \mathrm{L}$, and $10 \mu \mathrm{g} / \mathrm{L}$, respectively) [21]. These results also indicate that concentrations surpassed the limits established by Indonesian regulations for water [22]. The concentrations of $\mathrm{As}, \mathrm{Hg}$, and $\mathrm{Pb}$ in sediments are shown in Table 2. Concentrations of $\mathrm{As}, \mathrm{Hg}$, and $\mathrm{Pb}$ in sediment samples ranged from 16 to $120,000 \mu \mathrm{g} / \mathrm{g}$, not-detected (ND) to $790 \mu \mathrm{g} / \mathrm{g}$, and 24 to $10,700 \mu \mathrm{g} / \mathrm{g}$, respectively. These levels indicate that the sediment in Bone River is contaminated by those heavy metals and metalloids. The ND data can be obtained when a concentration is lower than the detection limit of the analytical instrument.

Table 1. Heavy metal concentrations in water samples from the upper course to the lower course of Bone River.

\begin{tabular}{ccccccc}
\hline \multirow{2}{*}{ Sample } & As & \multicolumn{2}{c}{ Hg } & \multicolumn{2}{c}{$\mathbf{P b}$} \\
\cline { 2 - 7 } & Concentration $(\mu \mathrm{g} / \mathrm{L})$ & SD & Concentration $(\mu \mathrm{g} / \mathrm{L})$ & SD & Concentration $(\mu \mathrm{g} / \mathrm{L})$ & SD \\
\hline W1 & 118 & 7 & 176 & 35 & 135 & 1 \\
W2 & 66 & 5 & 489 & 21 & 22 & 7 \\
W3 & 103 & 3 & 102 & 27 & 83 & 3 \\
W4 & 220 & 3 & 2080 & 6 & 1670 & 2 \\
W5 & 82,500 & 8 & 28 & 26 & 135 & 5 \\
W6 & 1690 & 1 & 744 & 11 & 581 & 2 \\
W7 & 10,800 & 2 & 37 & 7 & 26 & 4 \\
W8 & 1050 & 7 & 16 & 37 & 18 & 6 \\
W9 & 148 & 2 & 71 & 13 & 69 & 3 \\
W10 & 300 & 4 & 24 & 21 & 27 & 6 \\
W11 & 196 & 11 & 24 & 13 & 23 & 6 \\
\hline
\end{tabular}


Table 2. Heavy metal concentrations in sediment samples from the upper course to the lower course of Bone River.

\begin{tabular}{ccccccc}
\hline \multirow{2}{*}{ Sample } & \multicolumn{2}{c}{ As } & \multicolumn{2}{c}{$\mathbf{H g}$} & \multicolumn{2}{c}{$\mathbf{P b}$} \\
\cline { 2 - 7 } & Concentration $(\boldsymbol{\mu g} / \mathbf{g})$ & Error & Concentration $(\boldsymbol{\mu g} / \mathbf{g})$ & Error & Concentration $(\boldsymbol{\mu g} / \mathbf{g})$ & Error \\
\hline W1 & 62,100 & 5020 & 790 & 230 & 2660 & 1210 \\
W2 & 27,600 & 1380 & ND & ND & 843 & 891 \\
W3 & 120,000 & 23,100 & ND & ND & 10,700 & 4192 \\
W4 & 2030 & 77.4 & 57.9 & 22.3 & 4030 & 177 \\
W5 & 16.7 & 20.3 & 21.3 & 14.3 & 130 & 27.3 \\
W6 & 42 & 6 & ND & ND & 132 & 25 \\
W7 & 23.1 & 1.8 & ND & ND & 24.1 & 6.2 \\
W8 & 4.6 & 5.5 & ND & ND & 109 & 22 \\
W9 & 23.7 & 7.1 & 33 & 12.4 & 82.2 & 27.2 \\
W10 & 1250 & 61 & ND & ND & 1320 & 149 \\
W11 & 25 & 9 & 26 & 7 & 59 & 26 \\
\hline
\end{tabular}

Error: analytical error; ND: Not-detected.

The correlation between each element, which is shown in Figure 3, indicates that there is a positive correlation between $\mathrm{Hg}$ and $\mathrm{Pb}$ concentrations in water. $\mathrm{Hg}$ concentrations increase as $\mathrm{Pb}$ concentrations increase. In this study, the positive correlation between $\mathrm{Hg}$ and $\mathrm{Pb}$ is not well understood.

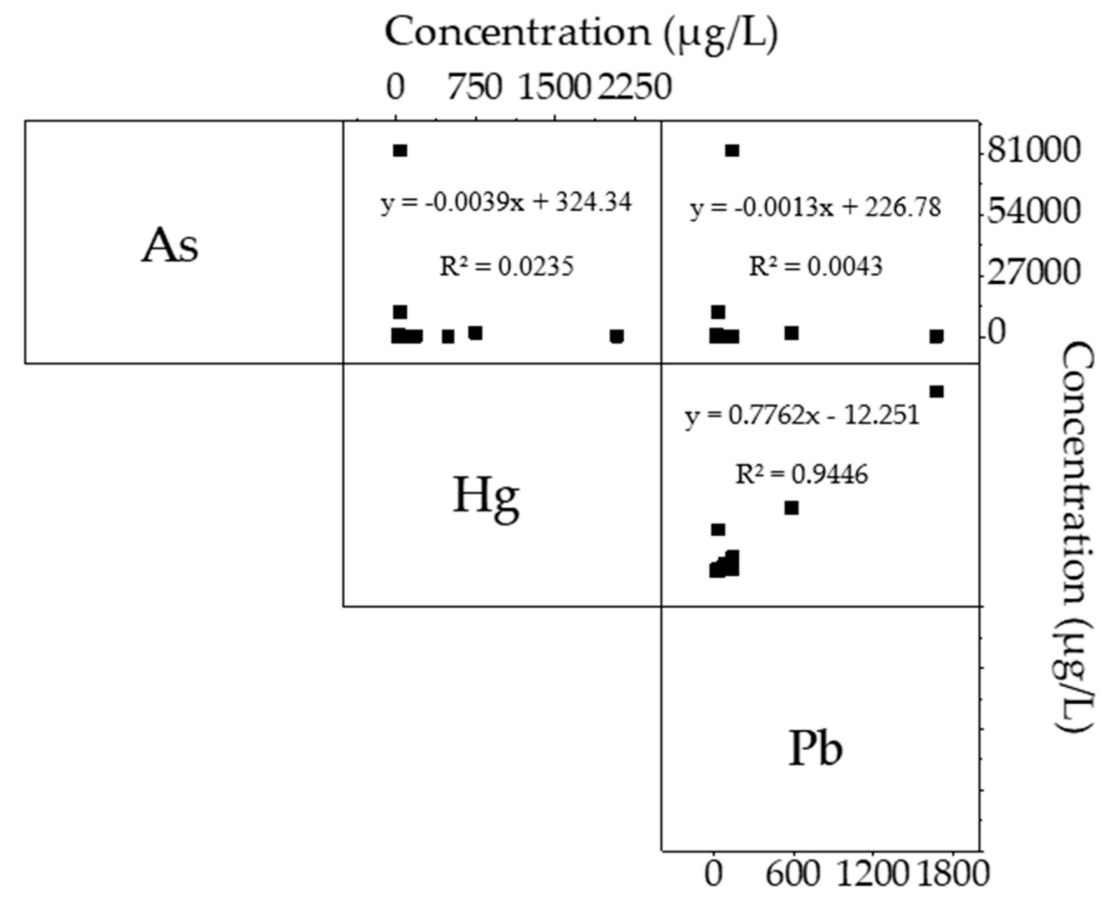

Figure 3. Relationship between $\mathrm{As}, \mathrm{Hg}$, and $\mathrm{Pb}$ in water samples from the upper course to the lower course of Bone River.

\section{Discussion}

\subsection{Heavy Metal Risk to the Aquatic System Due to ASGM Activities}

ASGM is currently practised in more than 70 countries, where it is mostly little acknowledged, unregulated, or illegal. This represents a large global emission source of $\mathrm{Hg}$ to the atmosphere, with estimates ranging from 20 to 37\% of anthropogenic $\mathrm{Hg}$ emissions [23-25]. The above result clearly shows that the $\mathrm{Hg}$ contaminations were originally from anthropogenic sources, which come from the use of mercury in the gold process. Most ASGM activities take place alongside streams and rivers because these activities require access to water for operations; this can pose a significant threat 
to aquatic ecosystems [26]. In this case, the $\mathrm{Hg}$ could be released into the aquatic system (e.g., at a watercourse near the ASGM site) and $\mathrm{Hg}$ could accumulate at the delta. The heavy metals and metalloids, such as $\mathrm{Hg}$, $\mathrm{Pb}$, As and sulfate ions, could also be leached into the stream and river through the surface and underground workings waste disposal by ASGM activities [27,28]. Thus, the high level of $\mathrm{Hg}, \mathrm{Pb}$, and As obtained in this study exist in the environment from those processes in ASGM. These heavy metals and metalloids are harmful to humans and environment.

\subsection{Mercury Pollution}

This research shows that Bone River has been polluted by $\mathrm{Hg}$, which is commonly known to come from elemental $\mathrm{Hg}$, which is used for gold extraction during ASGM activities. The $\mathrm{Hg}$ from mining sites could be released from the gold process and may find its way, in another form like methylmercury, into the water of Bone River and finally into the estuary of Gorontalo city. $\mathrm{Hg}$ is harmful to the human body, as it attacks the central nervous system and can lead to Minamata disease [29-32]. In this study, the Hg pollution in Bone River water comes from anthropogenic sources (i.e., from ASGM activity).

\subsection{Arsenic Pollution}

Either by natural or anthropogenic causes, high As concentrations in the environment are usually related with As-bearing parent rock materials also commonly present in sulfide rock deposits as As-sulfide minerals [28]. As concentrations in water from natural processes can be found in high concentrations, from $0 \mu \mathrm{g} / \mathrm{L}$ to more $5000 \mu \mathrm{g} / \mathrm{L}$, but are rarely found in much higher concentrations, especially in groundwater [33]. Commonly, As is mobilized in water when the $\mathrm{pH}$ value is about 6.5 to 8.5, under both oxidizing and reducing conditions [33]. Gold mining activities, which extract the ore from these rock deposits, will produce acid rock drainage (ARD), which has high acidity and can result in elevated levels of sulfate $\left(\mathrm{SO}_{4}{ }^{2-}\right), \mathrm{As}, \mathrm{Fe}$ and other toxic metals [34]. It may be a natural source of As pollution into the groundwater.

The gold ores and concentrates, containing some minerals that include metals and metalloids, need to be destroyed to get the gold [9,35]. The gold-bearing gold ore also contained As, crushed and spread over liquid mercury to remove the gold. In this study, the gold extraction processes not only used an elemental $\mathrm{Hg}$, but also cyanide. Other miners use both to produce the gold where, after crushing and milling the rocks into a fine grain and mixing with $\mathrm{Hg}$, the fine materials are put into a big box and are mixed with cyanide. Results of this study show extremely high concentrations of As in river water, compared to the natural As contamination of underground water in Bangladesh. The As concentration of underground water in Bangladesh reached up to about 500 to $4000 \mu \mathrm{g} / \mathrm{L}$, which is above the $50 \mathrm{mg} / \mathrm{L}$ limit set for drinking water in Bangladesh, and the $10 \mathrm{mg} / \mathrm{L}$ recommended by the World Health Organization $[9,20,36]$. The As concentration in water during this study reached up to $82,600 \mu \mathrm{g} / \mathrm{L}$, suggesting that the As contamination in this river water was not just from natural sources that occurred in a gold ore which contains As. Many other signs and symptoms have been reported in patients that have chronically ingested As, such as in West Bengal, India and Bangladesh [37-39]. In West Bengal, respiratory symptoms, crepitation, liver enlargement, and evidence of chronic arsenical dermatosis and hepatomegaly were prevalent $[40,41]$. Previous studies mentioned that skin cancer caused by As is usually accompanied by non-cancerous skin reactions and that the most common early symptoms are gastrointestinal, including diarrhea and abdominal pain $[37,42]$.

In the cyanidation process of getting gold, arsenic sulfides in the presence of oxygen are oxidized to arsenite and arsenate, with the distribution of each dependent on oxidation potential and $\mathrm{pH}$ [9]. The possibility of As being leached from the gold-cyanidation process is also related to the $\mathrm{pH}$, where in this study the miner is setting up the water and material conditions to be alkaline. Under alkaline conditions, gold can be found by leaching cyanidation, the arsenites could be formed on the dissolution of their sulfides [43]. 


\subsection{Lead Pollution}

ASGM activity, which includes techniques such as digging, crushing, panning and mixing that can be mixed with heavy metals and metalloids associated with gold such as $\mathrm{As}, \mathrm{Hg}$, and $\mathrm{Pb}[27,44-46]$. In this research, the concentration of $\mathrm{Pb}$ in water was higher than the WHO regulation, which is about $10 \mu \mathrm{g} / \mathrm{L}$ [20]. This result shows that $\mathrm{Pb}$ is toxic to human as well because it can cause severe gastrointestinal symptoms initially although no abnormalities were found on physical examination [47]. Even though $\mathrm{Pb}$ does not dissolve easily into the environment, it can mix with soil particles or dust and enter underground water or drinking water following rain and surface water runoff. Exposure of $\mathrm{Pb}$ can occur when eating food cultivated on soil with high $\mathrm{Pb}$ concentrations, drinking contaminated water, breathing polluted air and so on $[48,49]$.

\subsection{Practical Implication}

The contamination of rivers by chemicals leads to accumulation of these chemical substances in sediment. Thus, deposits act as a major sink of chemical pollutants such as heavy metals and metalloids. Sediments, therefore, contain an environmental record of pollutants that can be useful to establish the pollution history of a domain [50,51]. In this case, the pollutant could be solved to mitigate by the several solutions such as chemical precipitation, cementation, electrodeposition, solvent extraction, reverse osmosis, ion exchange and phytoremediation. Furthermore, constructing a lateral embayment in the river bank could serve as a control area where the pollutants could be naturally stored and then removed [52-54].

\section{Conclusions}

In this study, Bone River water has been polluted by $\mathrm{Hg}$, high As, and $\mathrm{Pb}$ from ASGM activity. We also showed that there are two sources of heavy metal and metalloid pollution in water of Bone River, with both a natural source of pollution and an anthropogenic source (i.e., ASGM). In the case of gold cyanidation, it has been restricted to arsenic and a lesser amount of Hg. The As minerals may dissolve through oxidation processes and in alkaline water, and the As can also be present in solution. However, much about the leaching of As to the environment from the gold processing through cyanidation processes, remains poorly understood. More research is required to elucidate their role and understand the harmful metals and metalloids in the gold process in ASGM.

Author Contributions: All authors contributed to the work presented in the manuscript; N.A.G. performed the study and wrote the paper; M.S., as Ph.D. Supervisor, provided advice, revised the paper, and gave recommendations on all analytical methods; S.S. provided advice and recommendations on the ICP-MS analysis; K.S. provided advice and recommendations on the PIXE analysis.

Funding: This research received was funded by the Japanese Government for providing funding, through JSPS KAKENHI Grant Number 16H02706 to M. Sakakibara for graduate study at Ehime University. Also was supported by the feasibility study "Social Acceptance of Regional Innovation for Reducing High-impact Environmental Pollution," Research Institute for Humanity and Nature (RIHN) Project Number 14200102.

Acknowledgments: The authors are thanks to the anonymous referees for their perceptive comments and recommendations. The authors give thanks to the government of Gorontalo Province, especially to Bone Bolango Regency and their stakeholders.

Conflicts of Interest: The authors declare no conflicts of interest.

\section{References}

1. Demirak, A.; Yilmaz, F.; Levent Tuna, A.; Ozdemir, N. Heavy metals in water, sediment and tissues of Leuciscus cephalus from a stream in southwestern Turkey. Chemosphere 2006, 63, 1451-1458. [CrossRef] [PubMed]

2. Choong, T.S.; Chuah, T.G.; Robiah, Y.; Koay, F.G.; Azni, I. Arsenic toxicity health hazards and removal techniques from water: An overview. Desalination 2007, 217, 139-166. [CrossRef] 
3. World Health Organisation. Health Risks of Heavy Metals from Long-Range Transboundary Air Poluution; World Health Organization: Geneva Switzerland, 2007; pp. 2-144.

4. Acosta, J.A.; Arocena, J.M.; Faz, A. Speciation of arsenic in bulk and rhizosphere soils from artisanal cooperative mines in Bolivia. Chemosphere 2015, 138, 1014-1020. [CrossRef] [PubMed]

5. Björkman, L.; Lundekvam, B.F.; Lægreid, T.; Bertelsen, B.I.; Morild, I.; Lilleng, P.; Lind, B.; Palm, B.; Vahter, M. Mercury in human brain, blood, muscle and toenails in relation to exposure: an autopsy study. Environ. Heal. 2007, 6, 30. [CrossRef] [PubMed]

6. Akpor, O.B.; Muchie, M. Remediation of heavy metals in drinking water and wastewater treatment systems: Processes and applications. Int. J. Phys. Sci. 2010, 5, 1807-1817.

7. Jarup, L. Hazards of heavy metal contamination. Br. Med. Bull. 2003, 68, 167-182. [CrossRef] [PubMed]

8. Loredo, J.; Soto, J.; Ordóñez, A.; Álvarez, R. Mercury and arsenic pollution associated to artisanal gold mining in huanca (Ayacucho Department, Peru). Fresenius Environ. Bull. 2009, 18, 391-398.

9. Kyle, J.H.; Breuer, P.L.; Bunney, K.G.; Pleysier, R. Review of trace toxic elements (Pb, Cd, Hg, As, Sb, Bi, Se, $\mathrm{Te})$ and their deportment in gold processing: Part II: Deportment in gold ore processing by cyanidation. Hydrometallurgy 2012, 111-112, 10-21. [CrossRef]

10. Feng, C.; Aldrich, C.; Eksteen, J.J.; Arrigan, D.W.M. Removal of arsenic from gold cyanidation process waters by use of cerium-based magnetic adsorbents. Miner. Eng. 2018, 122, 84-90. [CrossRef]

11. Fivaz, C. Presidential Address: How the MacArthur-Forrest cyanidation process ensured South Africa's golden future. J. S. Afr. Inst. Min. Metall. 1988, 88, 309-318.

12. Schleiss, A.J.; Franca, M.J.; Juez, C.; De Cesare, G. Reservoir sedimentation. J. Hydraul. Res. 2016, 54, 595-614. [CrossRef]

13. Islam, M.S.; Ahmed, M.K.; Raknuzzaman, M.; Habibullah-Al-Mamun, M.; Masunaga, S. Metal Speciation in Sediment and Their Bioaccumulation in Fish Species of Three Urban Rivers in Bangladesh. Arch. Environ. Contam. Toxicol. 2015, 68, 92-106. [CrossRef] [PubMed]

14. Heise, S.; Förstner, U. Risk assessment of contaminated sediments in river basins-Theoretical considerations and pragmatic approach. J. Environ. Monit. 2007, 9, 943-952. [CrossRef] [PubMed]

15. Japan International Cooperation Agency. The Study on Integrated Water Resources Management for Sefidrud River Basin in the Islamic Republic of Iran: A report. Available online: https:/ / www.jica.go.jp/english/ publications/reports/annual/2017/index.html (accessed on 21 May 2017).

16. National Institute of Standards \& Technology. Certificate of Analysis Standard Reference Material ${ }^{\circledR} 1643 \mathrm{f}$. Available online: https:/ / www-s.nist.gov/srmors/view_detail.cfm?srm=1643F (accessed on 6 April 2018).

17. Sera, K.; Yanagisawaa, T.; Tsunoda, H.; Futatsugawa, S.; Hatakeyama, S.; Saitoh, Y.; Suzuki, S. Bio-PIXE at the Takizawa facility (bio-PIXE with a baby cyclotron). Int. J. PIXE 1992, 2, 325-330. [CrossRef]

18. SPEX Certificate. Certificate of Reference Material XSTC-13. Available online: http://seishin-syoji.co.jp/ products/standard/standard004.html (accessed on 16 October 2018).

19. National Institute of Standards \& Technology. Certificate of Analysis Standard Reference Material ${ }^{2782}$. Available online: https:/ /www-s.nist.gov/srmors/view_detail.cfm?srm=2782 (accessed on 5 December 2014).

20. World Health Organisation. Guidelines for Drinking-Water Quality FIRST ADDENDUM TO THIRD EDITION; WHO: Geneva, Switzerland, 2006; Volume I, ISBN 92-4-1546964.

21. World Health Organisation. WHO's Drinking Water Standards. Available online: http:/ /www.lenntech.com/ applications/drinking/standards/who-s-drinking-water-standards.htm (accessed on 3 February 2017).

22. Palapa, T.M.; Maramis, A.A. Heavy Metals in Water of Stream Near an Amalgamation Tailing Ponds in Talawaan-Tatelu Gold Mining, North Sulawesi, Indonesia. Procedia Chem. 2015, 14, 428-436. [CrossRef]

23. Veiga, M.M.; Maxson, P.A.; Hylander, L.D. Origin and consumption of mercury in small-scale gold mining. J. Clean. Prod. 2006, 14, 436-447. [CrossRef]

24. Reichelt-Brushett, A.J.; Stone, J.; Howe, P.; Thomas, B.; Clark, M.; Male, Y.; Nanlohy, A.; Butcher, P. Geochemistry and mercury contamination in receiving environments of artisanal mining wastes and identified concerns for food safety. Environ. Res. 2017, 152, 407-418. [CrossRef] [PubMed]

25. Male, Y.T.; Reichelt-Brushett, A.J.; Pocock, M.; Nanlohy, A. Recent mercury contamination from artisanal gold mining on Buru Island, Indonesia-Potential future risks to environmental health and food safety. Mar. Pollut. Bull. 2013, 77, 428-433. [CrossRef] [PubMed] 
26. Macdonald, K.; Lund, M.; Blanchette, M. Impacts of Artisanal Small-Scale Gold Mining on Water Quality of a Tropical River (Surow River, Ghana). In Proceedings of the 10th International Conference on Acid Rock Drainage \& IMWA Annual Conference, Santiago, Chile, 21-24 April 2015; pp. 1-12.

27. Fashola, M.O.; Ngole-Jeme, V.M.; Babalola, O.O. Heavy Metal Pollution from Gold Mines: Environmental Effects and Bacterial Strategies for Resistance. Int. J. Environ. Res. Public Health 2016, 13, 1047. [CrossRef] [PubMed]

28. Rodriguez-freire, L.; Moore, S.E.; Sierra-alvarez, R.; Root, R.A.; Field, J.A. Arsenic remediation by formation of arsenic sulfide minerals in a continuous anaerobic bioreactor. Biotechnol. Bioeng. 2016, 113, 522-530. [CrossRef] [PubMed]

29. Gibb, H.; O'Leary, K.G. Mercury exposure and health impacts among individuals in the artisanal and small-scale gold mining community: A comprehensive review. Environ. Health Perspect. 2014, 122, 667-672. [CrossRef] [PubMed]

30. Hinton, J.; Veiga, M. Mercury Contaminated Sites: A Review of Remedial Solutions. In Proceedings of the NIMD (National Institute for Minamata Disease) Forum, Minamata, Japan, 19-20 March 2001.

31. Basu, A.; Phipps, S.; Long, R.; Essegbey, G.; Basu, N. Identification of response options to artisanal and small-scale gold mining (ASGM) in Ghana via the delphi process. Int. J. Environ. Res. Public Health 2015, 12, 11345-11363. [CrossRef] [PubMed]

32. Hachiya, N. The history and the present of Minamata disease-Entering the second half a century. Japan Med. Assoc. J. 2006, 49, 112-118.

33. Smedley, P.; Kinniburgh, D. A review of the source, behaviour and distribution of arsenic in natural waters. Appl. Geochem. 2002, 17, 517-568. [CrossRef]

34. Hayes, S.M.; Root, R.A.; Perdrial, N.; Maier, R.M.; Chorover, J. Surficial weathering of iron sulfide mine tailings under semi-arid climate. Geochim. Cosmochim. Acta 2014, 141, 240-257. [CrossRef] [PubMed]

35. Macdonald, K.; Lund, M.; Blanchette, M.; Mccullough, C. Regulation of artisanal small scale gold mining (ASGM) in Ghana and Indonesia as currently implemented fails to adequately protect aquatic ecosystems. In Proceedings of the 12th International Mine Water Association Congress, Xuzhou, China, 18-22 August 2014; pp. 401-405.

36. Ravenscroft, P.; Brammer, H.; Richards, K. Arsenic Pollution a Global Synthesis; Wiley-Blackwell: Hoboken, NJ, USA, 2009; ISBN 9780387280653.

37. Smith, A.H.; Lingas, E.O.; Rahman, M. Contamination of drinking-water by arsenic in Bangladesh: A public health emergency. Bull. World Health Organ. 2000, 78, 1093-1103. [CrossRef] [PubMed]

38. Akai, J.; Izumi, K.; Fukuhara, H.; Masuda, H.; Nakano, S.; Yoshimura, T.; Ohfuji, H.; Anawar, H.M.; Akai, K. Mineralogical and geomicrobiological investigations on groundwater arsenic enrichment in Bangladesh. Appl. Geochem. 2004, 19, 215-230. [CrossRef]

39. Karim, M.M. Arsenic in groundwater and health problems in Bangladesh. Water Res. 2000, 34, $304-310$. [CrossRef]

40. Mazumder, D.N.; Haque, R.; Ghosh, N.; De, B.K.; Santra, A.; Chakraborti, D.; Smith, A.H. Arsenic in drinking water and the prevalence of respiratory effects in West Bengal, India. Int. J. Epidemiol. 2000, 29, 1047-1052. [CrossRef] [PubMed]

41. Guha Mazumder, D.N.; Chakraborty, A.K.; Ghose, A.; Gupta, J.D.; Chakraborty, D.P.; Dey, S.B.; Chattopadhyay, N. Chronic arsenic toxicity from drinking tubewell water in rural West Bengal. Bull. World Health Organ. 1988, 66, 499-506. [PubMed]

42. WHO. Guidelines for Drinking Water Quality, Addendum to Volume 2: Health Criteria and Other Supporting Information; WHO publication: Geneva, Switzerland, 1998; pp. 1-283.

43. Marsden, J.; House, I. The Chemistry of Gold Extraction; Society for Mining, Metallurgy, and Exploration: Englewood, CO, USA, 2006; ISBN 0873352408.

44. Wilson, M.L.; Renne, E.; Roncoli, C.; Agyei-Baffour, P.; Tenkorang, E.Y. Integrated assessment of artisanal and small-scale gold mining in Ghana-Part 3: Social sciences and economics. Int. J. Environ. Res. Public Health 2015, 12, 8133-8156. [CrossRef] [PubMed]

45. Basu, N.; Clarke, E.; Green, A.; Calys-Tagoe, B.; Chan, L.; Dzodzomenyo, M.; Fobil, J.; Long, R.; Neitzel, R.; Obiri, S.; et al. Integrated Assessment of Artisanal and Small-Scale Gold Mining in Ghana-Part 1: Human Health Review. Int. J. Environ. Res. Public Health 2015, 12, 5143-5176. [CrossRef] [PubMed] 
46. Rajaee, M.; Obiri, S.; Green, A.; Long, R.; Cobbina, S.; Nartey, V.; Buck, D.; Antwi, E.; Basu, N. Integrated Assessment of Artisanal and Small-Scale Gold Mining in Ghana-Part 2: Natural Sciences Review. Int. J. Environ. Res. Public Health 2015, 12, 8971-9011. [CrossRef] [PubMed]

47. Koc, N.; Yu, A.; Gu, F. Severe Gastrointestinal Symptoms Due to Lead Poisoning From Indian Traditional Medicine Esophageal Squamous-Cell Papillomatosis Complicated by Carcinoma. Am. J. Gastroenterol. 2000, 95, 1591-1592.

48. Abdul-Wahab, S.; Marikar, F. The environmental impact of gold mines: Pollution by heavy metals. Open Eng. 2012, 2, 304-313. [CrossRef]

49. Ogola, J.S.; Mitullah, W.V.; Omulo, M.A. Impact of gold mining on the environment and human health: A case study in the Migori Gold Belt, Kenya. Environ. Geochem. Health 2002, 24, 141-158. [CrossRef]

50. Hogarh, J.N.; Adu-Gyamfi, E.; Nukpezah, D.; Akoto, O.; Adu-Kumi, S. Contamination from mercury and other heavy metals in a mining district in Ghana: Discerning recent trends from sediment core analysis. Environ. Syst. Res. 2016, 5, 15. [CrossRef]

51. Audry, S.; Schäfer, J.; Blanc, G.; Jouanneau, J.M. Fifty-year sedimentary record of heavy metal pollution $(\mathrm{Cd}, \mathrm{Zn}, \mathrm{Cu}, \mathrm{Pb})$ in the Lot River reservoirs (France). Environ. Pollut. 2004, 132, 413-426. [CrossRef] [PubMed]

52. Dean, J.G.; Bosqui, F.L.; Lanouette, K.H. Removing heavy metals from waste water. Environ. Sci. Technol. 1972, 6, 518-522. [CrossRef]

53. Peng, J.F.; Song, Y.H.; Yuan, P.; Cui, X.Y.; Qiu, G.L. The remediation of heavy metals contaminated sediment. J. Hazard. Mater. 2009, 161, 633-640. [CrossRef] [PubMed]

54. Juez, C.; Bühlmann, I.; Maechler, G.; Schleiss, A.J.; Franca, M.J. Transport of suspended sediments under the influence of bank macro-roughness. Earth Surf. Process. Landforms 2018, 43, 271-284. [CrossRef]

(C) 2018 by the authors. Licensee MDPI, Basel, Switzerland. This article is an open access article distributed under the terms and conditions of the Creative Commons Attribution (CC BY) license (http:// creativecommons.org/licenses/by/4.0/). 